\title{
Active immunization of heifers against a synthetic fragment of bovine inhibin
}

\author{
A. R. Scanlon ${ }^{1}$, S. J. Sunderland ${ }^{1 *}$, T. L. Martin ${ }^{2}$, D. Goulding ${ }^{1}$, \\ D. O'Callaghan ${ }^{1}$, D. H. Williams ${ }^{1}$, D. R. Headon ${ }^{3}$, M. P. Boland ${ }^{1}$, \\ J. J. Ireland ${ }^{2}$ and J. F. Roche ${ }^{1}$ \\ ${ }^{1}$ Agricultural and Veterinary Biotechnology Programme, University College Dublin, Ireland; \\ ${ }^{2}$ Molecular Reproductive Endocrinology Laboratory, Department of Animal Science, Michigan State \\ University, East Lansing, MI 48824, USA; and ${ }^{3}$ University College Galway, Ireland
}

Two experiments were conducted in cyclic beef heifers to determine whether active immunization against bovine inhibin $\alpha$ 1-26 Gly-Tyr (bINH) affected follicular dynamics, hormone concentration or ovulation rate. In Expt 1 , heifers $(n=9)$ were actively immunized against bINH conjugated to human $\alpha$ globulins (HAG) using bisdiazotized benzidine in nonulcerative Freund's adjuvant (NUFA; primary on day 0; booster injections on days 53,84 and 116 using conjugated bINH and on days 176 and 366 using unconjugated bINH; ten heifers were used as controls). Ovaries were examined daily using ultrasound scanning (days 70-155 and 384-391) and corresponding blood samples were collected for bINH antibody titre, luteinizing hormone ( $\mathrm{LH})$, follicle-stimulating hormone $(\mathrm{FSH})$ and oestradiol determinations. Four treated and four control heifers were injected with $10 \mu \mathrm{g}$ gonadotrophin-releasing hormone $(\mathrm{GnRH})$ on day 386 (day 2 of the oestrous cycle). Although bINH-immunized heifers had variable antibody titres ranging from 4 to $50 \% \mathrm{I}^{125}$-labelled bINH bound to serum diluted 1:2000, ovulation rate was unaffected. In oestrous cycles with three dominant follicles, the ovulatory follicles grew faster $\left(2.5 \pm 0.2\right.$ versus $1.6 \pm 0.3 \mathrm{~mm}$ day $^{-1}$; mean \pm SEM), had shorter durations of growth $(5.7 \pm 0.8$ versus $9.6 \pm 1.6$ days) and duration of detection ( $7.5 \pm 0.8$ versus $12.0 \pm 2.4$ days) in immunized heifers. Mean concentrations of FSH, LH and oestradiol were unaltered in most cases during oestrous cycles in bINH-immunized compared with control heifers. There was no significant difference in the percentage increase in FSH or $\mathrm{LH}$, after GnRH injection, between control and immunized heifers. As ovulation rate was unaltered in the first experiment, a second similar study was designed using a different immunization protocol. In Expt 2, heifers were immunized with bINH conjugated to human serum albumin using glutaraldehyde with the following doses: 0.0 (control; $n=7), 0.33(n=7), 1.0(n=8)$ and $3.0(n=7) \mathrm{mg}$. Three booster immunizations were given 33, 66 and 209 days after primary immunization. Immunization increased the number of oestrous cycles with multiple ovulations (42 of $132(32 \%)$ oestrous cycles examined) compared with controls ( 1 of 30 (3.3\%) oestrous cycles examined). Neither titre nor ovulation rate was affected by dose of bINH used. In summary, following bINH immunization, ovulation rate was not increased despite changes in follicular dynamics in Expt 1 , but was increased in $32 \%$ of oestrous cycles in Expt 2 . We conclude that immunization protocols can affect responsiveness of heifers to bINH immunization, and that immunization against inhibin can increase ovulation rate.

\section{Introduction}

Cows normally ovulate a single dominant follicle, resulting in a low incidence of twin births. A dominant follicle is the largest follicle on the ovary; it suppresses growth of other follicles while continuing its own growth (Goodman and Hodgen, 1983;

${ }^{*}$ Corresponding author: S. J. Sunderland, Faculty of Veterinary Medicine, University College Dublin, Ballsbridge, Dublin 4, Ireland.

Received 26 February 1992.
Ireland and Roche, 1987). After ovulation, a group of follicles is recruited, one of which is selected to become dominant (Ireland and Roche, 1987). During the oestrous cycle of cattle, two (Pierson and Ginther, 1984; Knopf et al., 1989) or three (Ireland and Roche, 1987; Savio et al., 1988; Sirois and Fortune, 1988) dominant follicles develop and undergo either atresia or ovulation. Although nutrition alters turnover of dominant follicles in heifers (Murphy et al., 1991), the factors that regulate dominant follicle growth are unknown. 


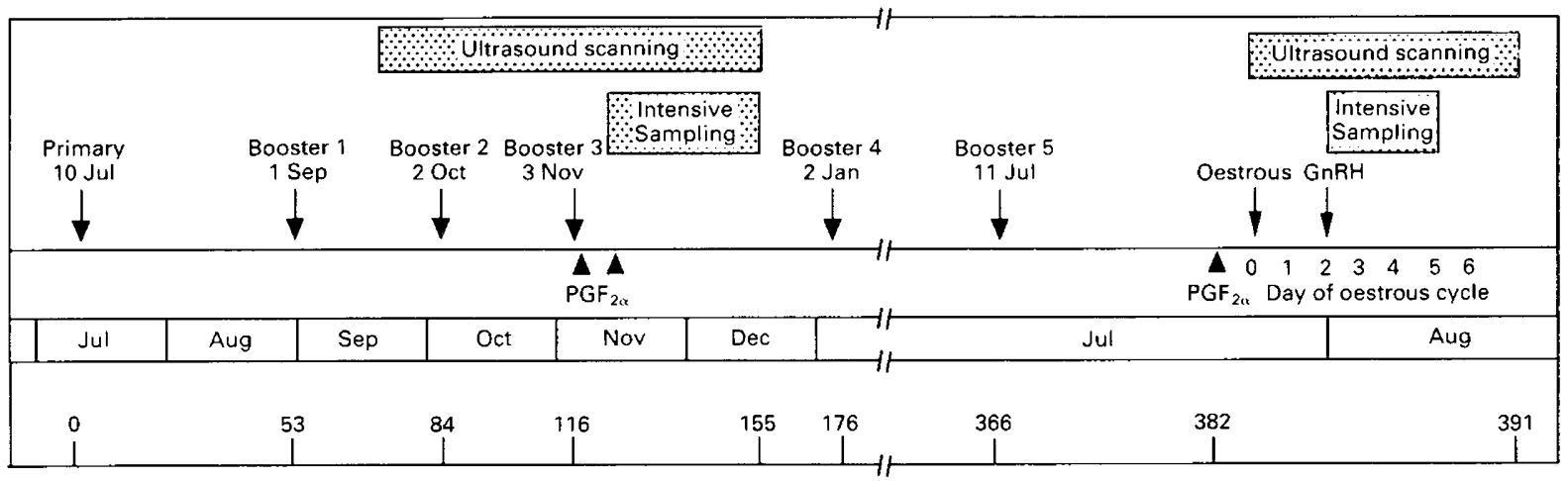

Days of experiment

Fig. 1. Protocol for Expt 1. Heifers $(n=9)$ were given a primary immunization against bovine inhibin $\alpha$ 1-26 Gly-Tyr (bINH) conjugated to human $\alpha$ globulins on day 0 (10 July 1989) and boosters on days 53,84, 116, 176 and 366 . Control heifers $(n=10)$ received a placebo on the same days. Four bINH immunized and four control heifers received a single gonadotrophin-releasing hormone $(\mathrm{GnRH}$ ) injection 16 days after the 5 th boost (day 386). Ovaries were examined daily by ultrasound from day 70 to day 155 and day 384 to day 391. Blood samples were collected weekly from day 53 to day 164 , day 176 to day 258 and from day 358 to day 399. Blood samples were also collected at 2-4 h intervals from day 126 to 155 and at 15 min to $12 \mathrm{~h}$ intervals at about the time of $\mathrm{GnRH}$ injection (intensive sampling). Prostaglandin $\mathrm{F}_{2 \alpha}\left(\mathrm{PGF}_{2 \alpha}\right)$ was administered three times as indicated.

Inhibins are dimeric $(\alpha-\beta$ A, $\alpha-\beta$ B) glycoprotein hormones secreted predominantly by granulosa cells of the follicle. They have a negative feedback effect on the secretion of folliclestimulating hormone (FSH) (De Jong, 1988). Inhibin secretion, in turn, is increased by increasing FSH concentrations (Bicsak $e t$ al., 1986; Tsonis et al., 1988; Buckler et al., 1989; McNeilly et al., 1989). Thus, it can be hypothesized that inhibins, through their systemic role in suppressing FSH, have an important role in maintaining the ovulation of only one follicle in cattle.

In support of a role for inhibin in regulating gonadal function, active immunization against purified synthetic or recombinant inhibin $\alpha$-subunit peptides, interrupts the negative feedback effect of inhibins on FSH secretion. This results in increased blood FSH concentrations, ovulation rate and spermatogenesis in many domestic species. Specifically, immunization against peptides from the carboxy region of the $\alpha$-subunit of inhibin increased ovulation rate in rats (Rivier and Vale, 1989), ewes (Voglmayr et al., 1990; Wrathall et al., 1990; Boland et al., 1991), gilts (Brown et al., 1990; King et al., 1990) and increased spermatogenesis in bulls (Martin et al., 1991a; Schanbacher, 1991) and rams (Voglmayr et al., 1990). In contrast, immunization against a peptide from the amino region of the $\alpha$-subunit of inhibin suppressed ovulation rate in sheep (Findlay et al., 1989a). These results indicate that inhibin-based immunization procedures may be an important new method for regulating fertility in domestic species.

In heifers, intrafollicular concentrations of inhibins decrease during development of the dominant ovulatory follicle, but increase during development of the dominant non-ovulatory follicle (Martin et al., 1991b). On the basis of these results and those from other laboratories, we hypothesized that inhibins have an important role in regulation of growth, differentiation and ovulatory quota of dominant follicles during the oestrous cycle of heifers. This hypothesis was tested by actively immunizing heifers against the $\alpha(1-26)$ subunit of $32 \mathrm{kDa}$ bovine inhibin in two different studies. The objective of Expt 1 was to determine the effects of immunoneutralization of inhibin on follicular dynamics, ovulation rate and serum concentrations of FSH, luteinizing hormone (LH) and oestradiol and FSH and LH secretion induced by gonadotrophin-releasing hormone $(\mathrm{GnRH})$. As ovulation rate was not altered in the first study, despite development of antibodies to the $\alpha(1-26)$ inhibin subunit and alterations in follicular turnover, a second experiment was carried out with ovulation rate as the only parameter measured. In Expt 2, multiple doses of $\alpha(1-26)$ inhibin, a different carrier protein, conjugation procedure, site of injection and immunization schedule were used to evaluate further effects of active immunization against the $\alpha(1-26)$ inhibin peptide on ovulation rate in heifers.

\section{Materials and Methods}

\section{Experiment 1}

Animals and treatments. Nine cyclic crossbred beef heifers (14-18 months old) were immunized with bovine inhibin $\alpha$ 1-26 Gly-Tyr (bINH) conjugated to human $\alpha$ globulins (HAG) by bisdiazotized benzidine (Martin et al., 1991a, b). Ratio of weight of bINH:HAG after conjugation was approximately 2:1. Amounts of bINH in bINH-HAG for primary immunization and for boosters 1 to 3 , and the amount of free bINH in boosters 4 and 5 injected per heifer were as follows: primary $1.3 \mathrm{mg}$ bINH in $0.5 \mathrm{ml}$ saline emulsified in $1 \mathrm{ml}$ Corynebacterium parvum (Wellcome Ireland Ltd) and $1.5 \mathrm{ml}$ non-ulcerative Freund's adjuvant (NUFA; Guildhay Antisera Ltd, Guildford, Surrey); boosters 1 to 3 - as above except heifers received $0.72 \mathrm{mg}$ bINH on day 53 and $0.5 \mathrm{mg}$ bINH on days 84 and 116 without Corynebacterium parvum; boosters 4 and 5 with unconjugated bINH alone - as above except heifers received $0.5 \mathrm{mg}$ free bINH on days 176 and 366 (Fig. 1). Control heifers $(n=10)$ received $0.7 \mathrm{mg} \mathrm{HAG}$ (primary and boosters $I$ to 3 ) or saline (boosters 4 and 5) emulsified as explained above. All injections were given subcutaneously in two sites in the neck or behind the shoulder. 
Ovarian ultrasonography. Ovaries of heifers were examined, using ultrasound, daily from day 70 to day 155 and day 384 to day 391 using the method described by Savio et al. (1988) and Murphy et al. (1990). Definitions used for describing follicular dynamics were similar to those reported by Savio et al. (1988). In brief, follicles $5-9 \mathrm{~mm}$ in diameter were defined as medium and follicles $\geq 10 \mathrm{~mm}$ as large. Definitions of follicle characteristics used were: maximum size - the largest diameter obtained (mm); day of maximum diameter - the day at which the maximum diameter of the follicle was obtained; duration of growth - the number of days between the first measurement of the follicle and maximum size plus one day (one day was added to take account of the plateau in growth rate); growth rate - the maximum size divided by the duration of growth $\left(\mathrm{mm}\right.$ day $^{-1}$ ); duration of atresia - the number of days between the day of maximum diameter and the last observation of the follicle plus one day; rate of atresia - the maximum size divided by the duration of atresia; duration of detection - the sum of duration of growth and atresia for the follicle. Ovulation was determined by the disappearance of a dominant follicle from the ovary and subsequent formation of a corpus luteum in the position previously occupied by the dominant follicle. Heifers were divided into those with two or three dominant follicles per oestrous cycle. Where possible, data from the first cycle of each heifer with two or three dominant follicles were included in the subsequent statistical analysis (nine 3-dominant follicle and nine 2-dominant follicle oestrous cycles from bINH heifers and five 3-dominant follicle and ten 2-dominant follicle cycles from control heifers).

Blood samples for titres and hormone concentrations. For examination of titres of bINH antibodies, blood samples were collected by jugular venepuncture once per week from day 53 to day 164 after boosters 1 to 3 and from day 176 to day 258 after booster 4 and day 358 to day 399 after booster 5 (Fig. 1). Bovine INH antibody titres were determined by incubating radiolabelled bINH with $200 \mu \mathrm{l}$ serum diluted at 1:1000, 1:2000, 1:4000 and 1:8000 (Martin et al., 1991a). Percentage of radiolabelled bINH bound at 1:2000 dilution (on linear portion of dilution curve) of serum was used in presentation of bINH antibody titres.

To establish whether active immunization against inhibins altered hormonal secretion patterns and (or) follicular turnover, all heifers were given a luteolytic dose of prostaglandin $\mathrm{F}_{2 \alpha}$ analogue $\left(\mathrm{PGF}_{2, a^{\prime}} ; 500 \mu \mathrm{g}\right.$ of cloprostenol; Estrumate, Coopers Ltd, Bray, Wicklow, Ireland) on days 117 and 127 after booster 3 (Fig. 1) to synchronize their oestrous cycles. All heifers were checked daily for oestrus (day $0=$ oestrus), and the ovaries of each heifer were examined daily by ultrasound, as described. Concentrations of FSH, LH and oestradiol were determined in serum samples collected between day 126 and day 155 (single oestrous cycle) in bINH-immunized and control heifers. Heifers were fitted with an indwelling jugular cannula and blood samples were taken at $4 \mathrm{~h}$ intervals from $24 \mathrm{~h}$ before the second $\mathrm{PGF}_{2 \alpha}$ dose until $36 \mathrm{~h}$ after $\mathrm{PGF}_{2 \alpha}$ administration. Heifers were then sampled every $2 \mathrm{~h}$ until 4 days after ovulation and subsequently every $4 \mathrm{~h}$ until after the next ovulation which was approximately 20 days later.

To determine whether active immunization against inhibins altered pituitary responsiveness of heifers to GnRH, we gave seven control and seven bINH-immunized heifers a single injection of $\mathrm{PGF}_{2 \alpha} 16$ days after booster 5 (day 382; Fig. 1). On day 2 of the subsequent oestrous cycle, four of the seven immunized and four control heifers were given $10 \mu \mathrm{g} \mathrm{GnRH} \mathrm{(Op.} \mathrm{C} \mathrm{089,}$ Hoechst AG, Frankfurt, Germany) intravenously. Blood samples were collected at $-60,-30,0,+15,+30,+60,+120$, $+240,+360,+720$ and +1440 min relative to $\mathrm{GnRH}$ administration. Daily ultrasound examination was used to determine the effects of GnRH on follicular dynamics until the next ovulation.

After collection, blood samples were incubated at room temperature for $\mathrm{Ih}$ and overnight at $4^{\circ} \mathrm{C}$. Samples were then centrifuged at $700 \mathrm{~g}$ for $20 \mathrm{~min}$; the serum was decanted and stored at $-20^{\circ} \mathrm{C}$ until assayed.

Hormone assays. All blood samples collected during the oestrous cycle and after the $\mathrm{GnRH}$ challenge were assayed for $\mathrm{LH}$ and FSH. LH concentrations were determined using the method of Niswender et al. (1969). The bLH used for iodination and standards was USDA-bLH-I-1. The LH antiserum was NIDDK-anti oLH-1 (AFP 192279). Interassay coefficient of variation $(\mathrm{CV})$ for three bovine serum pools of 1.6, 6.4 and $12.8 \mathrm{ng} \mathrm{ml}^{-1}$ was $15.8,8.9$ and $7.9 \%$, respectively. Intra-assay $\mathrm{CV}$ for the same serum pools was $10.2,6.8$ and $7.2 \%$, respectively. Sensitivity of the bLH assay was $0.7 \mathrm{ng} \mathrm{ml}^{-1}$. The FSH used for iodination was NIDDK oFSH-I-I (AFP 5679C). The standard FSH was bFSH-B-I and the antiserum was anti-oFSH (rabbit) NIDDK (AFP C5288113). Interassay CV for three bovine serum pools of 38,68 and $120 \mathrm{ng} \mathrm{ml}^{-1}$ was 10.7,6.4 and $9.0 \%$, respectively. Intra-assay CV for the same serum pool was $5.2,4.8$ and $4.9 \%$, respectively. Sensitivity of the FSH assay was $25 \mathrm{ng} \mathrm{ml}^{-1}$.

Oestradiol concentrations were determined in blood samples collected at $12 \mathrm{~h}$ intervals during the oestrous cycle using the radioimmunoassay described by Moran et al. (1991). Interassay $\mathrm{CV}$ for three bovine serum pools of $2.5,5.0$ and $10.0 \mathrm{pg} \mathrm{ml}^{-1}$ were $16.2,12.1$ and $13.3 \%$, respectively. Intra-assay $\mathrm{CV}$ for the same serum pools were $10.9,10.2$ and $9.5 \%$, respectively. Sensitivity of the oestradiol assay was $2 \mathrm{pg} \mathrm{ml}^{-1}$.

Statistical analysis. Follicle characteristics as determined by ultrasound examination were analysed using one-way analysis of variance. For LH and FSH analysis, four (inclusive) periods relative to the peak of the LH surge (hour 0 ) were used: (1) preLH surge $(-40$ to $-8 \mathrm{~h}$ ), (2) during the LH surge $(-4$ to $4 \mathrm{~h}$ ), (3) after LH surge ( 4 to $40 \mathrm{~h}$ ) and (4) between LH surges (44 to $416 \mathrm{~h}$ ). The periods used for the oestradiol analyses were (hours relative to the $\mathrm{LH}$ surge inclusive): (1) pre-LH surge ( -96 to $-36 \mathrm{~h}$ ), (2) during the LH surge ( -24 to $24 \mathrm{~h}$ ), (3) after-LH surge $(36$ to $96 \mathrm{~h}$ ), and (4) between surges (108 to $588 \mathrm{~h}$ ). Within each period, a split-plot analysis of variance was performed on the log-transformed data. The methods outlined in Milliken and Johnson (1984) were used to obtain correct standard errors and $P$ values, and took into account the imbalance in the data caused by missing values. In the case of a significant time by treatment interaction, the split-plot provided a $t$ test of the immunization effect at each time point, and where insignificant, an $F$ test for the main effect of immunization. In the case of blood samples collected at about the time of GnRH 


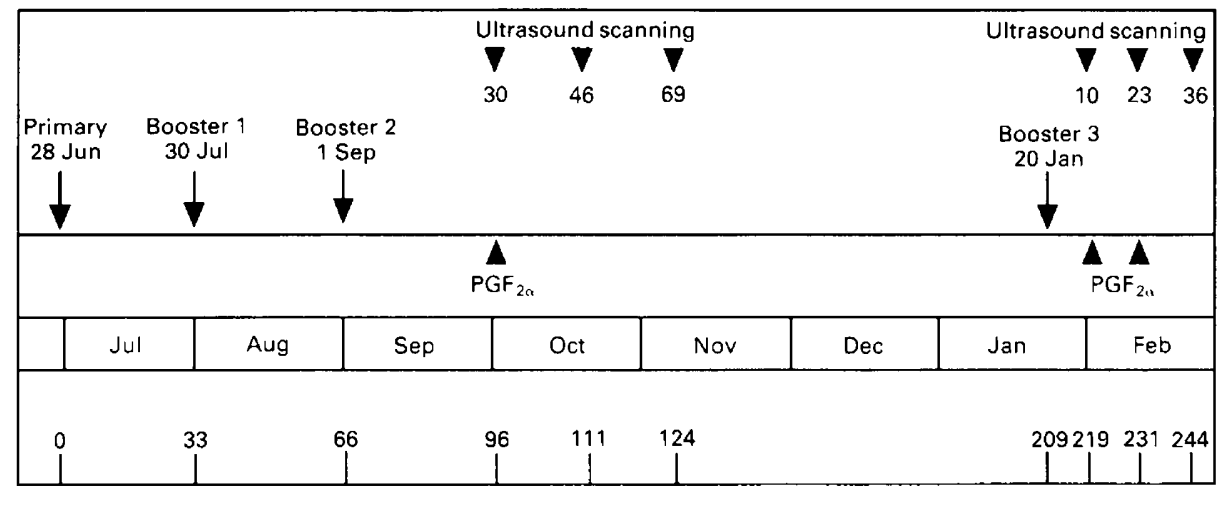

Days of experiment

Fig. 2. Protocol for Expt 2. Heifers were randomly allocated to one of four treatments, $0.0 \mathrm{mg}$ control $(n=7), 0.33 \mathrm{mg}$ bovine inhibin $\alpha$ 1-26 Gly-Tyr (bINH) $(n=7), 1.0 \mathrm{mg}$ bINH $(n=8)$ and $3.0 \mathrm{mg}$ bINH $(n=7$ ). Each group received a primary immunization against bINH-HSA on day 0 (28 June 1990) followed by boosters on days 33,66 and 209. Ovaries of all heifers were examined by ultrasound on six occasions, three times after booster 2 on days 96,111 and 124 and three times after booster 3 on days 219, 231 and 244. These days corresponded to 30, 46 and 69 days after booster 2 and 10,23 and 36 days after booster 3 . Prostaglandin $\mathrm{F}_{2 \alpha}\left(\mathrm{PGF}_{2 \alpha}\right)$ was administered three times, once after booster 2 on day 96 and twice after booster 3 on days 219 and 231 .

injection, the percentage increase in LH and FSH concentrations (relative to the mean concentration before injection) was analysed using the same method.

\section{Experiment 2}

Animals and treatments. Owing to the fact that ovulation rate was unaltered in heifers in Expt 1, conjugation procedure, carrier protein, dose of immunogen and site of injection were all altered to re-examine the effect of immunization against bINH on ovulation rate. The overall experimental protocol showing date of primary and booster immunizations, and ultrasound scanning is given (Fig. 2). Mature cyclic crossbred beef heifers were allocated at random to be immunized with: (i) $0.0 \mathrm{mg}$ placebo (adjuvant and saline) controls $(n=7)$, (ii) $0.33 \mathrm{mg}$ ( $n=7)$, (iii) $1.0 \mathrm{mg}(n=8)$ and (iv) $3.0 \mathrm{mg}(n=7) \mathrm{bINH}$. The bovine inhibin (1-26) Gly-Tyr peptide was synthesized at University College Galway, Ireland and conjugated by the glutaraldehyde method (Reichlin, 1980) to human serum albumin (HSA). Ratio of weight of bINH:HSA after conjugation was approximately 1:1 and it was emulsified as in Expt 1 in non-ulcerative Freund's adjuvant and injected subcutaneously in two sites in the brisket region. Primary immunization (day 0) including Corynebacterium parvum was followed by three booster immunizations on days 33,66 and 209 using the same dose of immunogen but without Corynebacterium parvum as given in the primary injection.

Ovarian ultrasonography. In contrast to Expt 1 , ovaries of heifers were examined by ultrasound only once during six different oestrous cycles per heifer to determine ovulation rate. To ensure different oestrous cycles were used for determination of ovulation rate, $\mathrm{PGF}_{2 \alpha}$ was given to heifers as outlined (Fig. 2).

Blood samples for titre determination. After primary immunization, blood samples were taken at 7-14-day intervals up to day 124 and again from day 209 to day 244 for antibody titre determinations as described for Expt 1 .

Statistical analysis. The data on antibody titres were transformed to log values and analysed using both the overall mean for all blood samples and the maximum value after the first and second boosters. A one-way analysis of variance was used to test for differences in titres at different immunogen dose concentrations. The effect of immunization on the number of oestrous cycles with multiple ovulations was analysed using mean ovulation rates over time for the three groups of immunized heifers by a Wilcoxon sum test. The effect of titre on ovulation rate was examined by classifying immunized heifers into three ovulatory groups during the period when the ovulation rates were high (days 23 to 46), as single only, single or multiples, and multiples only. The relationships between antibody titres and ovulation rates in these three groups were analysed using analysis of variance and a two group unpaired $t$ test after both boosters 2 and 3. This relationship was also examined by determining the regression coefficients between all antibody titres and all ovulation rates on days 10, 23, 30, 36, 46 and 69 . Differences in ovulation rate on days $10,23,30,36$, 46 and 69 following booster immunizations were analysed using $\chi^{2}$ analysis.

\section{Results}

\section{Experiment 1}

Inhibin antibody titres. Antibody titres were highly variable (4-50\% at 1:2000 dilution) in immunized heifers and began to rise 10-14 days after the first, second and third boosters (Fig. 3a). After the third booster, antibody titres remained high for approximately 2 weeks in all bINH immunized heifers and then began to decline. Antibody titres following the fourth booster 
(a)
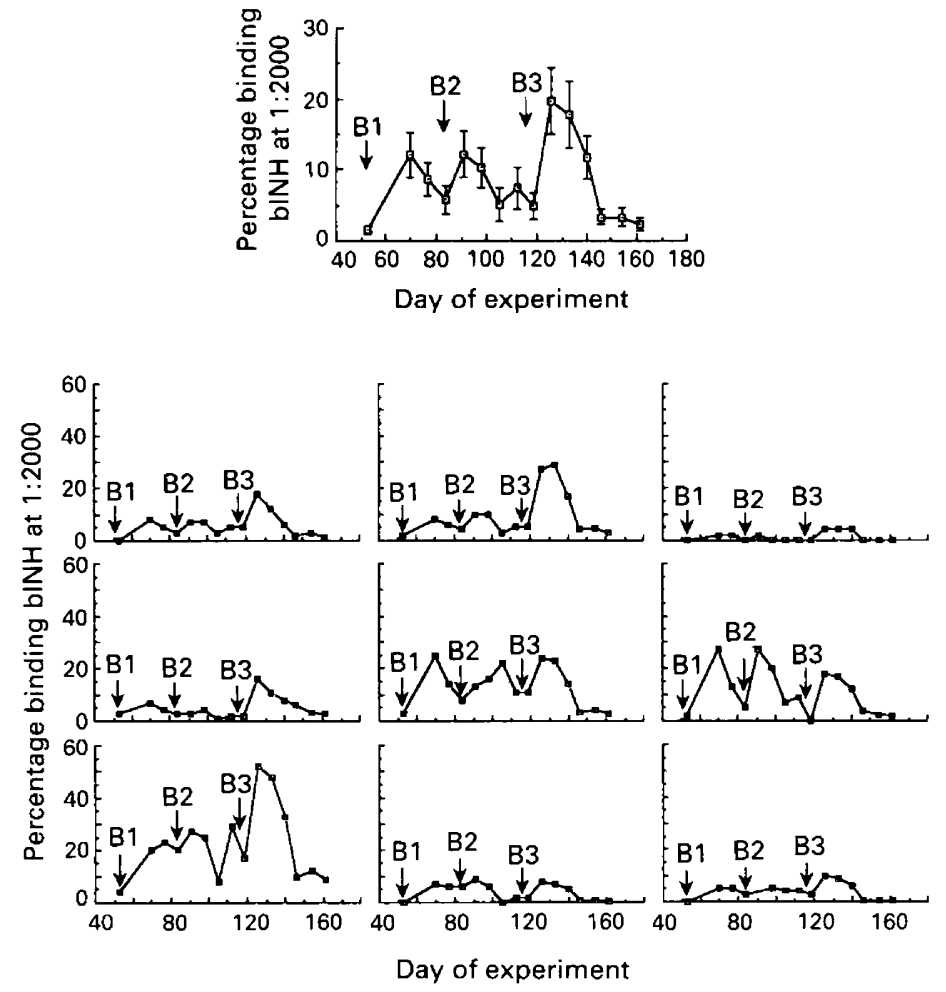

(b)
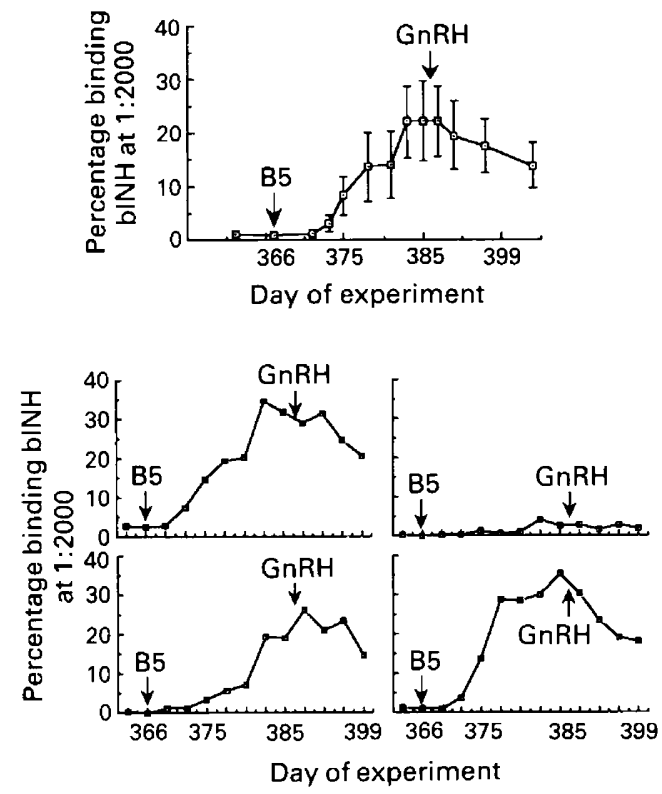

Fig. 3. (a) Mean ( \pm SEM) (upper panel) and individual antibody titres (lower panel) to bovine inhibin $\alpha$ 1-26 Gly-Tyr (bINH) (\% radioiodinated bINH bound at $1: 2000$ ) after boosters (B) 1 to 3 for nine bINH-immunized heifers (day 53 to 164) in Expt 1 . Note different scales on the vertical axis of mean and individual plots. (b) Mean ( \pm SEM) (upper panel) and individual antibody titres (lower panel) to bINH after booster 5 (day 358 to 399 ) for four immunized heifers given GnRH. Throughout the experiment, antibody titres of control animals were consistently at non-specific binding values.

(unconjugated bINH) were not increased $(<5 \%$ binding at $\mathrm{I}: 2000$ ), whereas 10 to 17 days after the fifth booster, antibody titres increased (range 5-35\% binding at 1:2000 dilution) and persisted for approximately 3 weeks (Fig. 3b).

Follicular dynamics. After ultrasound examination between day 70 and day 155, heifers were divided into those with two or three dominant follicles per oestrous cycle as described in the methods section. During oestrous cycles with three dominant follicles, the ovulatory follicle grew faster $(P<0.05 ; 2.5 \pm 0.2$ versus $1.6 \pm 0.3 \mathrm{~mm}$ day $\left.^{-1}\right)$, had a shorter duration of growth $(P<0.05 ; 5.7 \pm 0.8$ versus $9.6 \pm 1.6$ days $)$ and duration of detection $(P<0.05 ; 7.5 \pm 0.8$ versus $12.0 \pm 2.4$ days $)$ in bINH-immunized heifers compared with controls. Other follicular parameters of oestrous cycles in heifers with three dominant follicles and all follicular parameters of oestrous cycles in heifers with two dominant follicles were similar between control and bINH heifers. All heifers had a single ovulation in all oestrous cycles examined (47 and 44 oestrous cycles in control and immunized heifers, respectively). No differences in follicular dynamics or ovulation rate were detected between bINH immunized and control heifers following GnRH injection.

Hormone concentrations. There was no significant difference in concentrations of LH, FSH or oestradiol observed when bINH-immunized heifers were compared with controls during the pre-LH surge period ( 40 to $8 \mathrm{~h}$ before the $\mathrm{LH}$ surge), during the LH surge ( -4 to $4 \mathrm{~h}$ after surge) or between $\mathrm{LH}$ surges (44 to $416 \mathrm{~h}$ after LH surge). However during the period after the LH surge ( 4 to $40 \mathrm{~h}$ after surge) there was a significant increase in $\mathrm{LH}\left(P<0.05 ; 2.6\right.$ versus $\left.1.6 \mathrm{ng} \mathrm{ml}^{-1}\right)$ in immunized heifers compared with controls and a significant $(P<0.04)$ time $x$ treatment interaction for oestradiol.

During the period of the experiment when $\mathrm{GnRH}$ was given (day 382), FSH concentrations in bINH-immunized heifers were higher than in controls $(P<0.002$; Fig. 4). A significant increase in both FSH $(P \leqslant 0.03)$ and LH $P \leqslant 0.01)$ was obtained following GnRH injection in both control and bINH heifers. However, the percentage increase in FSH or $\mathrm{LH}$ after the GnRH injection in bINH immunized heifers was not different from control heifers $(P>0.05)$.

Experiment 2. Data from two control heifers were excluded from the experiment due to illness. The dose of immunogen used did not affect the mean antibody titres nor the ovulatory response $(P>0.05)$ obtained in immunized heifers (Fig. 5); hence data on titres and ovulation rate in heifers given different doses of immunogen were pooled. The number of oestrous cycles that had multiple ovulations was increased in the immunized heifers (42 of $132(32 \%)$ oestrous cycles for 22 heifers) compared with control heifers ( 1 of $30(3.3 \%$ ) oestrous cycles for five heifers). In relation to the association between titres and ovulation rate during the period when multiple ovulations occurred in immunized heifers, there was no significant relationship between mean titres (\% binding at 1:2000) and multiple ovulations after booster 2 . However, after booster 3 , 

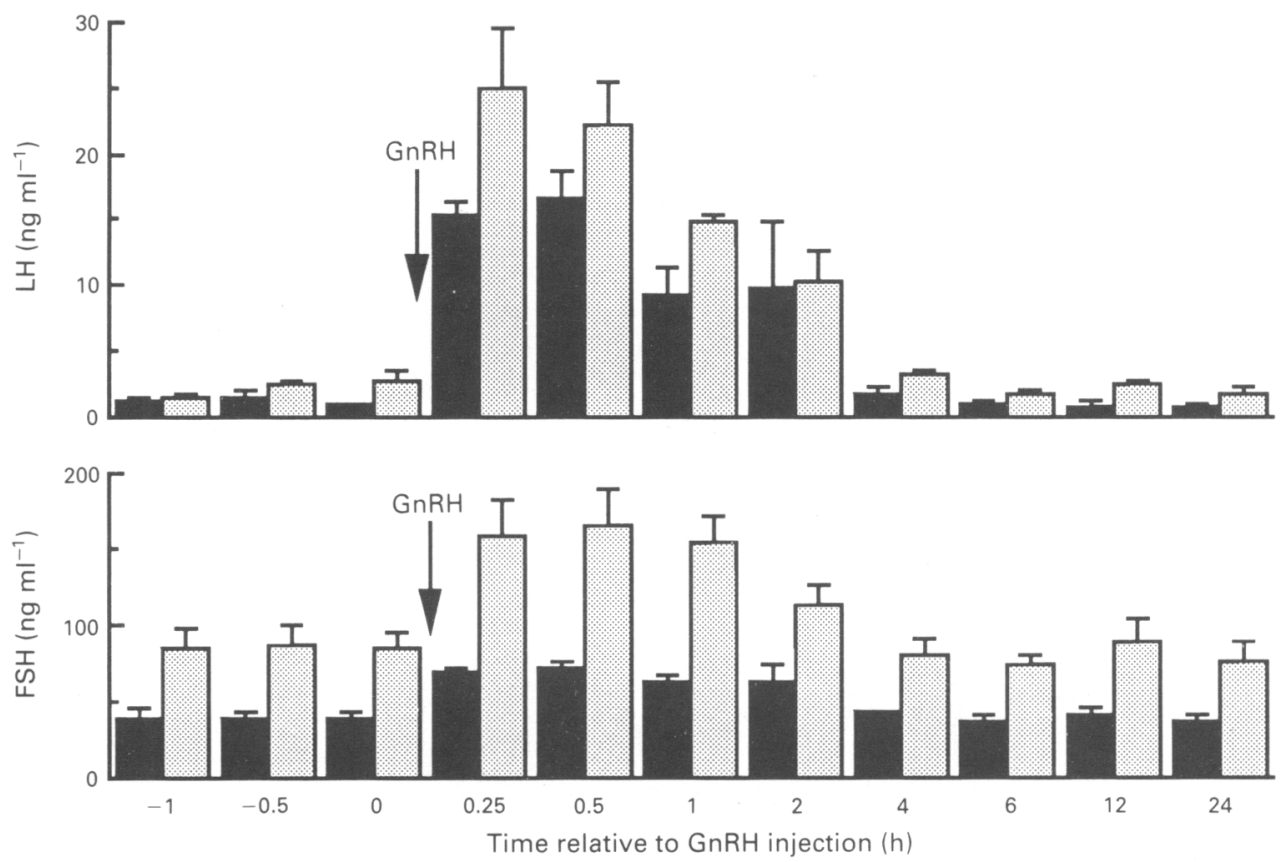

Fig. 4. Mean ( \pm SEM) serum concentrations of luteinizing hormone $(\mathrm{LH})$ and follicle-stimulating hormone (FSH) in ( $\square$ ) control heifers and (图) heifers immunized against bovine inhibin $\alpha$ 1-26 Gly-Tyr (bINH) at the time of gonadotrophin-releasing hormone $(\mathrm{GnRH})$ injection (arrow; day 386) in Expt 1. GnRH (10 $\mu \mathrm{g}$ ) was given intravenously on day 2 of the oestrous cycle (day $0=$ day of oestrus). Blood samples were collected frequently for $1 \mathrm{~h}$ before and $24 \mathrm{~h}$ after injection.

the mean titres were higher $(P<0.05)$ during oestrous cycles with multiple ovulations $(38.7 \pm 3.6 \%)$ than in oestrous cycles with singles only (11.6 $\pm 3.1 \%)$ or cycles with either single or multiple ovulations $(20.3 \pm 8.8 \%)$. The duration of increased ovulation rate following a booster immunization was examined by combining data from booster 2 and 3, because heifers were scanned at different times relative to these two boosters (Fig. 2). There was a significant increase $(P<0.04)$ in the numbers of heifers with multiple ovulations on days 36 and 46 after boosters than in controls on the same day, but the numbers with multiple ovulations on days 10,23,30 and 69 were not different $(P>0.05)$. The number of days after a booster, however, altered the proportion of oestrous cycles with multiple ovulations since 1 of $22(5 \%), 39$ of $88(44 \%)$ and 2 of 22 $(9 \%)$ oestrous cycles had multiple ovulations within 10 days, between 23 and 46 days or at 69 days after booster immunization, respectively (Table 1 ). Because of the short duration of occurrence of multiple ovulations, the examination of data on the consistency of multiple ovulations within the same heifer was restricted to two oestrous cycles; 16 of 44 (35\%) heifers had single ovulations, I1 of $44(25 \%)$ had multiples at each cycle, and 17 of $44(39 \%)$ had a single or multiple ovulation at the two oestrous cycles examined.

\section{Discussion}

The most significant result of our study was that immunization of beef heifers with bINH conjugated to human serum albumin increased ovulation rate in $32 \%$ of oestrous cycles of immunized heifers examined in the second experiment. Although previous studies examining the effect of inhibin immunization have usually been restricted to a single oestrous cycle, other laboratories have also reported positive effects of inhibin immunization on ovulation rate in heifers (Glencross et al., 1990), sheep (Forage et al., 1987; Findlay et al., 1989b; Wrathall et al., 1990; Mizumachi et al., 1990), gilts (Brown et al., 1990; King et al., 1990) and rats (Rivier and Vale, 1989). However, responsiveness of heifers to immunization with bINH conjugates in these studies was highly variable and unpredictable. For example, although bINH conjugated to human $\alpha$ globulins or to human serum albumin consistently elicited moderate titres of bINH antibodies, titres of bINH antibodies were highly variable among heifers in Expts 1 and 2 and only $32 \%$ of oestrous cycles of heifers in Expt 2 had multiple ovulations. Moreover, persistence of moderate bINH antibody titres was transient, lasting only up to three weeks after multiple boosters. Changes in concentrations of hormones and dynamics of follicular growth and ovulation rate (in Expt 1 and after booster 2 in Expt 2) were unrelated to titre of bINH antibodies. Despite the fact that titres of bINH antibodies generated in Expt 1 were similar to titres in Expt 2, some but not all heifers in Expt 2 had multiple ovulations. This surprising result emphasizes that other factors as well as antibody titre may be important for increasing ovulation rate in heifers. The simplest explanation for the differences between results of Expts 1 and 2 could be that antibodies generated to bINH:HAG in Expt 1 did not neutralize endogenous inhibin, thus explaining why mean patterns of serum FSH concentrations and ovulation rate were unaltered in this study. This explanation, however, seems unlikely for two reasons. First, the 
(a)

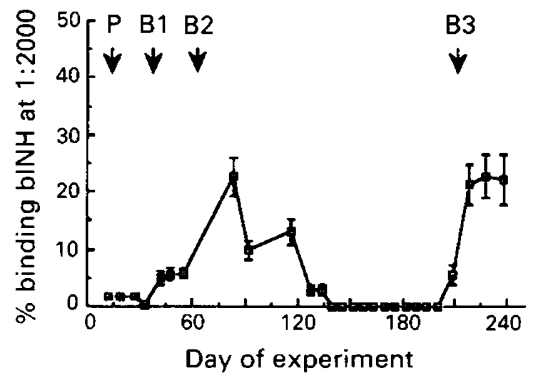

(b)
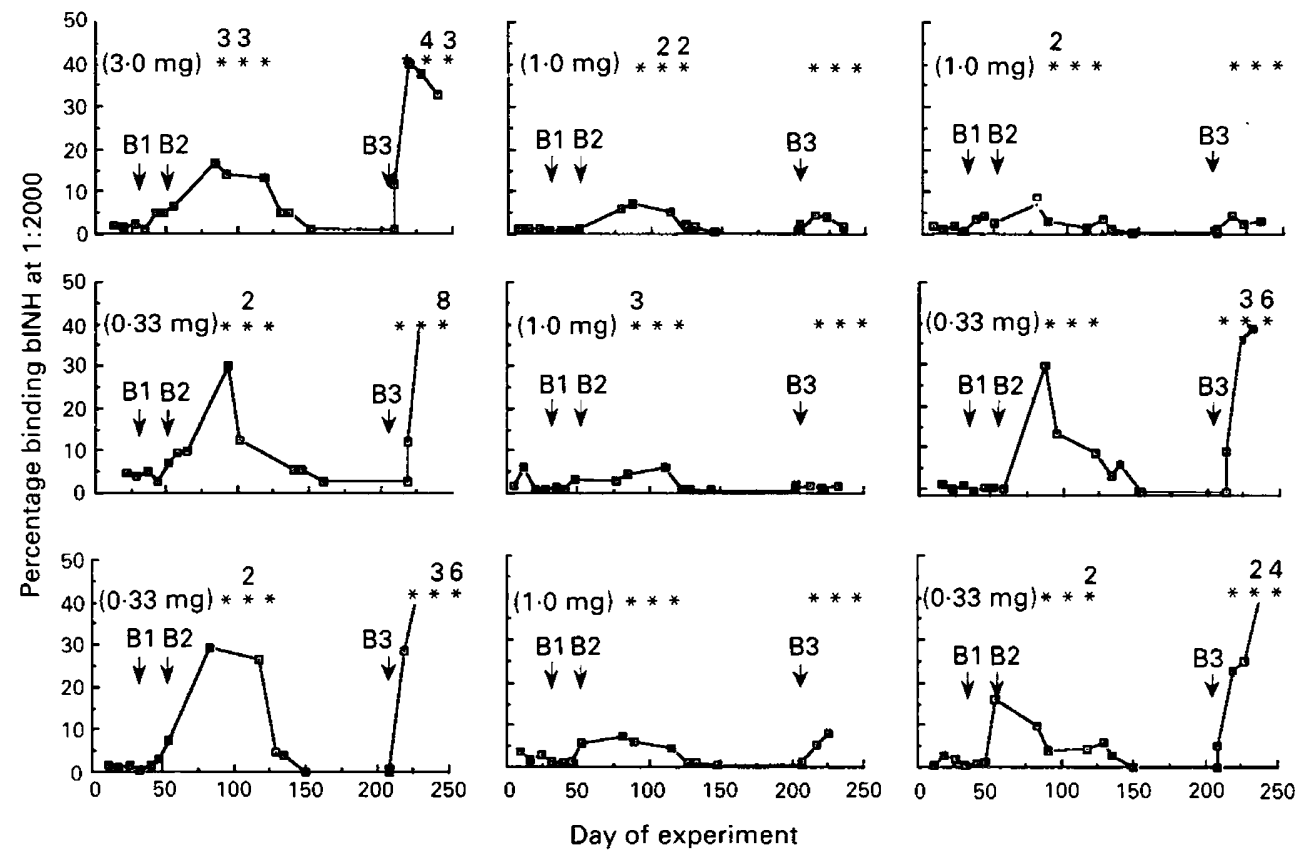

Fig. 5. (a) Mean ( \pm SEM) antibody titre to bovine inhibin $\alpha$ I-26 Gly-Tyr (bINH) (\% radioiodinated bINH bound at 1:2000) of all immunized heifers $(n=22)$ during Expt 2. Primary (P) was given on day 0, booster 1 (B1) day 33, booster 2 (B2) day 66 and booster 3 (B3) day 209. (b) Individual antibody titres following bINH immunization in nine representative heifers. Times of examination by ultrasound are marked by ${ }^{*}$. The corresponding number above the ${ }^{*}$ indicates the ovulation rate in heifers with multiple ovulations.

Table 1. The effect of interval from previous booster immunization on the number of heifers with multiple ovulations and the range in multiple ovulations in heifers immunized against bovine inhibin $\alpha 1-26 \mathrm{Gly}$-Tyr in Expt 2 as determined by ultrasound scanning

after booster 3

Days from previous booster

Days of ovarian examination (after booster)

Number of immunized heifers scanned

Number of heifers with multiple ovulations

2 ovulations

3 ovulations

$\geq 4$ ovulations

$R$ value of the relationship between antibody titre and ovulation rate

$\begin{array}{rrr}10 & 23 & 36 \\ 22 & 22 & 22 \\ 1 & 8 & 1 \\ 1 & 2 & \\ - & 5 & \\ - & 1 & 6\end{array}$

0.40

0.60

0.89

0.08

0.42

0.04

${ }^{*}$ Number of heifers with multiple ovulations was different from controls $(P<0.05) \chi^{2}$ analysis. 
amino acid sequence of the bINH peptide used in each study was the same. Second, because the peptide sequences for bINH were exactly alike, it is unlikely that the bINH peptide used for immunizations in Expt 1 had an epitope(s) that resulted in formation of predominantly non-neutralizing antibodies. However, alterations in bINH epitopes caused by differences in carrier proteins, conjugation procedures or stability of conjugates could have resulted in differences in neutralization capacity or affinity of the bINH antibodies generated following immunization of heifers (Briand et al., 1985; Goubau et al., 1989; Grieger and Reeves, 1990). These possibilities were not tested in our study.

Another possible explanation for the variability in response of heifers to bINH immunization is the dose of bINH used. However, data from Expt 2 did not demonstrate a significant relationship between dose of immunogen used and either antibody titre or ovulation rate in immunized heifers. It is possible that higher amounts of free $\alpha$ subunit are present in bovine serum than in serum of other species. The effect of this on immunization response is not known. High concentrations of antibodies may be required to neutralize both the active inhibin and the free $\alpha$ subunit. Thus, the lack of change in ovulation rate in bINH-immunized heifers in Expt 1 may be due to the failure of the immunization protocol to immunoneutralize all active inhibin. This suggestion, however, is not substantiated from results in Expt 2, where $32 \%$ of oestrous cycles examined had multiple ovulations with antibody titres in a similar range to those in Expt 1. It is unlikely, therefore, that it is the inability of the antibodies to bind all the $\alpha$ subunit that results in the poor ovulatory response in immunized heifers in Expt 1. Although the reason for variability in biological responses of heifers immunized against bINH is unknown, our results suggest that low doses of bINH conjugated to human serum albumin by the glutaraldehyde procedure will stimulate multiple ovulations in heifers.

Follicular turnover in Expt I was markedly altered in bINHimmunized heifers with three dominant follicles per oestrous cycle, in the absence of any related changes in hormone concentrations. Although the reasons for this phenomenon are unclear, recent evidence suggests that inhibins or their subunits may have local effects on gonadal function (Ying et al., 1986; Hsueh et al., 1987; Gonzalez-Manchon and Vale, 1989; Lin et al., 1989; O et al., 1989; Tsafriri et al., 1989; Woodruff et al., 1990). A report by Schneyer et al. (1991) indicated that inhibin $\alpha$ subunits bind to FSH receptor sites and inhibit FSH bioactivity in granulosa cells. The relative importance of the endocrine effects of inhibin on FSH secretion compared with the direct effects of inhibins or inhibin subunits on gonadal function are unknown. McNeilly et al. (1991) concluded that the effects of inhibin immunization on increasing follicular growth are related to a positive endocrine effect on FSH secretion. Consequently, because no increase in mean FSH concentrations was detected in heifers in Expt 1, this may explain why the ovulation rate was also unchanged. Nevertheless, recent results from our laboratory support autocrine or paracrine role(s) for inhibins or inhibin subunits in regulation of gonadal function. For example, passive immunization of heifers against inhibins suppresses oestradiol production without altering changes in serum concentrations of gonadotrophins (Martin et al., 1990). Moreover, despite increased concentrations of FSH in the above study, ovulation rate was unaltered. King et al. (1990) found that immunization of gilts against inhibin increased ovulation rate but did not alter concentrations of gonadotrophins and in another study active immunization of gilts against inhibin blocked compensatory ovarian hypertrophy but did not alter concentrations of gonadotrophins (King et al., 1991). On the basis of these results, it is possible that immunization against inhibins or inhibin subunits has positive or negative local effects on gonadal function. Whether negative local effects of neutralization of inhibins are offset by positive effects of inhibin neutralization on FSH secretion may depend on numerous factors including characteristics (titre, affinity, persistence) of inhibin antibodies or stage of reproductive cycle.

Steroid feedback may also confound effects of inhibin neutralization on FSH secretion. For example, increased FSH secretion after inhibin immunoneutralization should increase serum concentrations of oestradiol. The increased negative feedback effects of oestradiol on FSH secretion would, in turn, reduce secretion of FSH and offset the positive feedback effects of inhibin immunoneutralization on FSH secretion. The time of neutralization of FSH by inhibin during the oestrous cycle may be important in relation to the effect on ovulation rate and relate to specific phases of recruitment and selection of follicles.

Not only was there a discrepancy in ovulatory response in heifers between Expt 1 and Expt 2, but also within Expt 2, where there was an apparent difference in relationship between mean antibody titres and multiple ovulations following measurements made at different times relative to the boosters. During the period of occurrence of multiple ovulations after booster two, there was no association between mean titre and multiple ovulations, whereas after the third booster, animals with multiple ovulations had significantly increased antibody titres compared with titres in heifers with single or a combination of single and multiple ovulations. This introduces another variable in determining the ovulatory response to bINH immunization and suggests that ovulation rate in some circumstances is related to antibody titres. It also demonstrates that the approach of immunization against bINH has potential in developing a new method to superovulate cattle.

Absence of a difference in the effect of GnRH between both bINH immunized and control heifers on LH and FSH secretion in our study contrasts with reports by Findlay et al. (1989b) and Wrathall et al. (1990) in immunized ewes. However, their results are controversial because of the lack of, or differential responses of FSH or LH to GnRH following inhibin immunizations. Reasons for these discrepancies among experiments are unknown, but may be related to factors already discussed.

The immune response of heifers to bINH immunization was highly variable, titre of bINH antibodies was not related to dose of immunogen or time after booster and did not affect responsiveness to $\mathrm{GnRH}$, follicular dynamics, hormone concentrations or ovulation rate. Immunization of heifers against bINH:HSA, but not bINH:HAG, enhanced ovulation rate. In conclusion, immunization of heifers with bINH:HSA may be beneficial in enhancing ovulation rate in heifers.

The authors thank N. Hynes, S. McDonnell, G. Claffey, and S. NiCeallaigh for laboratory assistance; M. Crowe, A. Donovan, P. Duffy, W. Enright, M. Finnerty, F. Griffith, L. Vaughan and D. O'Donohue for technical assistance; NIAMDD, NIDDK, NICHHD 
and USDA for assay reagents; G. Niswender for LH antiserum; $M$. Kane (UCG) for peptide synthesis and conjugation. The authors thank Kildagan Stud, Kildare, Ireland for the supply and care of the heifers. Research was supported by UCD Agricultural and Veterinary Biotechnology Programme and USDA grants (88-37240-4104 and 90-372405508 ) to J. J. Ireland. J. J. Ireland is a member of the National Center for Infertility Research at Michigan State University. Abstracts of these data were presented at the 1990 winter meeting and 1991 Annual Conference of the Society for Study of Fertility.

\section{References}

Bicsak TA, Tucker EM, Scott C, Vaughan J, Rivier J, Vale W and Hsueh AJW (1986) Hormonal regulation of granulosa cell inhibin biosynthesis Endocrinology 119 2711-2719

Boland MP, Kane M, Headon D, Williams DH, Goulding D, Sunderland SJ and Roche JF (1991) Persistence of increased ovulation rate in ewes immunized aganst the $\alpha$ 1-26 fragment of inhibin Journal of Reproduction and Fertility Abstract Series 7 Abstract 41

Briand JP, Muller S and Van Regenmortel MHV (1985) Synthetic peptides as antigens: pitfalls of conjugation methods Journal of Immunological Methods $\mathbf{7 8}$ $59-69$

Brown RW, Hungerford JW, Greenwood PE, Bloor RJ, Evans DF, Tsonis CG and Forage RG (1990) Immunization against recombinant bovine inhibin $\alpha$ subunit causes increased ovulation rate in gilts Joumal of Reproduction and Fertility $90199-205$

Buckler HM, Healy DL and Burger HG (1989) Purified FSH stimulates production of inhibin by the human ovary Journal of Endocrinology 122 279-285

De Jong FH (1988) Inhibin Physiological Reviews 68 555-607

Findlay JK, Tsonis CG, Doughton B, Brown RW, Bertram KC, Braid GH, Hudson GC. Tierney ML, Goss NH and Forage RG (1989a) Immunisation against the amino-terminal peptide $\left(\alpha_{N}\right)$ of the alpha ${ }_{43}$ subunit of inhibin impairs fertility in sheep Endocrinology 124 3122-3124

Findlay JK, Doughton B, Robertson DM and Forage RG (1989b) Effects of immunization against recombinant bovine inhibin $\alpha$ subunit on circulating concentrations of gonadotrophins in ewes Journal of Endocrinology 120 59-65

Forage RG, Brown RW, Oliver KJ, Atrache BT, Devine PL, Hudson GC, Goss NH, Bertram KC, Tolstoshev P, Robertson DM, de Kretser DM, Doughton B, Burger HG and Findlay JK (1987) Immunization against an inhibin subunit produced by recombinant DNA techniques results in increased ovulation rate in sheep Journal of Endocrinology 114 RI-R4

Glencross RG, Bleach EC, McLeod BJ, Beard AJ and Knight PG (1990) Increased ovulation rate in heifers immunized against a synthetic peptide sequence of bovine inhibin Journal of Reproduction and Fertility Abstract Series 6 Abstract 30

Gonzalez-Manchon C and Vale W (1989) Activin-A, inhibin and transforming growth factor- $\beta$ modulate growth of two gonadal cell lines Endocrinology 125 1666-1672

Goodman AL and Hodgen GD (1983) The ovarian triad of the primate menstrual cycle Recent Progress in Hormone Research 39 1-73

Goubau S, Silversides DW, Gonzalez A, Laarveld B, Mapletoft RJ and Murphy BD (1989) Immunization of sheep against modified peptides of gonadotropin releasing hormone conjugated to carriers Domestic Animal Endocrinology 6 339-347

Grieger DM and Reeves JJ (1990) Active immunization of beef heifers against luteinizing hormone: II. Evaluation of conjugation technique on antigenicity of LH Journal of Animal Science 68 3747-3754

Grieger DM, Scarborough R, deAvila DM, Johnson HE and Reeves JJ (1990) Active immunization of beef heifers against luteinizing hormone: III. Evaluation of dose and longevity Journal of Animal Science 68 3755-3764

Hsueh AJW, Dahl KD, Vaughan J, Tucker E, Rivier J, Bardin CW and Vale W (1987) Heterodimers and homodimers of inhibin subunits have different paracrine action in the modulating of luteinizing hormone-stimulated androgen biosynthesis Proceedings of the National Academy of Science USA $\mathbf{8 4}$ $5082-5086$

Ireland JJ and Roche JF (1987) Hypotheses regarding development of dominant follicles during a bovine estrous cycle. In Follicular growth and ovulation rate in farm animals, pp 1-18 Eds JF Roche and D O'Callaghan. Martinus Nijhoff, Dordrecht

King BF, Sesti LAC, Britt JH, Esbenshade KL, Flowers B and Ireland JJ (1990) Enhancement of ovulation rate by immunization of gilts against inhibin Journal of Animal Science 68413 (Abstract 437)
King BF, Sesti LAC, Britt JH, Esbenshade KL, Flowers B and Ireland JJ (1991) Effect of active immunization of gilts against inhibin on ovarian compensation following unilateral ovariectomy Joumal of Animal Science 69433 (Abstract 583)

Knoft L, Kastelic JP, Schallenberger E and Ginther OJ (1989) Ovarian follicular dynamics in heifers: test of two wave hypothesis by ultrasonically monitoring individual follicles Domestic Animal Endocrinology 6 111-119

Lin T, Calkins J, Morris PL, Vale W and Bardin CW (1989) Regulation of Leydig cell function in primary culture by inhibin and activin Endocrinology 125 2134-2140

McNeilly AS, Swanston IA, Crow W, Tsonis CG and Baird DT (1989) Changes in the plasma concentration of inhibin throughout the normal sheep oestrous cycle and after the infusion of FSH Journal of Endocrinology 120 295-305

McNeilly AS, Crow W and Campbell BK (1991) Effect of follicular fluid and inhibin immunoneutralization on FSH-induced preovulatory follicle growth in the ewe Joumal of Endocrinology 131 401-409

Martin TL, Scanlon AR, Sunderland SJ, Boland MP, Roche JF and Ireland JJ (1990) Evidence for a role of inhibins in function of dominant follicles and corpora lutea in heifers Biology of Reproduction 42123 (Abstract 247)

Martin TL, Williams GL, Lunstra DD and Ireland JJ (1991a) Immunoneutralization of inhibin modifies hormone secretion and sperm production in bulls Biology of Reproduction 45 73-77

Martin TL, FogwelI RL and Ireland JJ (1991b) Concentrations of inhibins and steroids in follicular fluid during development of dominant follicles in heifers Biology of Reproduction 44 693-700

Milliken GA and Johnson DE (1984) Analysis of messy data. Vol. 1: Designed experiments. Lifetime Learning Publications, Belmont, CA

Mizumachi M, Voglmayr JK, Washington DW, Chen CLC and Bardin CW (1990) Superovulation of ewes immunized against the human recombinant inhibin $\alpha$-subunit associated with increased pre- and postovulatory folliclestimulating hormone levels Endocrinology 126 1058-1063

Moran C, Quirke JF, Prendiville DJ, Bourke S and Roche JF (I99I) The effect of estradiol, trenbolone acetate, or zeranol on growth rate, mammary development, carcass traits and plasma estradiol concentrations of beef heifers Journal of Animal Science 69 4249-4258

Murphy MG, Boland MP and Roche JF (1990) Pattern of follicular growth and resumption of ovarian activity in post-partum beef suckler cows joumal of Reproduction and Fertility 90 523-533

Murphy MG, Enright WJ, Crowe MA, McConnell K, Spicer LJ, Boland MP and Roche JF (1991) Effect of dietary intake on pattern of growth of dominant follicles during the oestrous cycle in beef heifers Journal of Reproduction and Fertility 92 333-338

Niswender GD, Reichert LE Jr, Midgley AR Jr and Nalbandov AV (1969) Radioimmunoassay for bovine and ovine luteinizing hormone Endocrinology 84 1166-1173

O WS, Robertson DM and de Kretser DM (1989) Inhibin as an oocyte meiotic inhibitor Molecular and Cellular Endocrinology 62 307-311

Pierson RA and Ginther OJ (1984) Ultrasonography of the bovine ovary Theriogenology 21 495-504

Reichlin M (1980) Use of glutaraldehyde as a coupling agent for proteins and peptides. In Methods in Enzymology, pp 159-165 Eds HV Vanakis and IJ Langone. Academic Press, NY

Rivier C and Vale W (1989) Immunoneutralization of endogenous inhibin modifies hormone secretion and ovulation rate in the rat Endocrinology 125 152-157

Savio JD, Keenan L, Boland MP and Roche JF (1988) Pattern of growth of dominant follicles during the oestrous cycle of heifers Journal of Reproduction and Fertility $83663-671$

Schanbacher BD (1991) Pituitary and testicular responses of beef bulls to active immunization against inhibin alpha Journal of Animal Science $69252-257$

Schneyer AL, Sluss PM, Whitcomb RW, Martin KA, Sprengel R and Crowley WF Jr (1991) Precursors of $\alpha$-inhibin modulate follicle-stimulating hormone receptor binding and biological activity Endocrinology 129 1987-1999

Sirois J and Fortune JE (1988) Ultrasonographic monitoring of ovarian follicular dynamics during the estrous cycle in heifers Theriogenology 29308

Tsafriri A, Vale W and Hsueh AJW (1989) Effects of transforming growth factors and inhibin-related proteins on rat preovulatory graafian follicles in vitro Endocrinology 125 1857-1862

Tsonis CG, Messinis IE, Templeton AA, McNeilly AS and Baird DT (1988) Gonadotropic stimulation of inhibin secretion by the human ovary during the 
follicular and early luteal phase of the cycle Joumal of Clinical Endocrinology \& Metabolism $66915-921$

Voglmayr JK, Mizumachi M, Washington DW, Chen CC and Bardin CW (1990) Immunization of rams against human recombinant inhibin $\alpha$-subunit delays, augments, and extends season-related increase in blood gonadotropin levels Biology of Reproduction 42 81-86

Woodruff TK, Lyon RJ, Hansen SE, Rice GC and Mather JP (1990) Inhibin and activin locally regulate rat ovarian folliculogenesis Endocrinology 127 3196-3205
Wrathall JHM, McLeon BJ, Glencross RG, Beard AJ and Knight PG (1990) Inhibin immunoneutralization by antibodies raised against synthetic peptide sequences of inhibin $\alpha$ subunit: effects on gonadotrophin concentrations and ovulation rate in sheep Journal of Endocrinology 124 167-176

Ying SY, Becker A, Ling N and Guillemin R (1986) Inhibin and beta type transforming growth factor (TGFB) have opposite modulating effects on the follicle stimulating hormone ( $\mathrm{FSH}$ )-induced aromatase activity of cultured rat granulosal cells Biochemical and Biophysical Research Communications 136 969-975 